\title{
Idiopathic polypoidal choroidal vasculopathy masquerading as choroidal tumors: one year follow-up of a peripheral lesion
}

\author{
Vasculopatia polipoidal idiopática da coroide simulando tumores da coroide: \\ um ano de seguimento de uma lesão periférica
}

Rony Carlos Preti ${ }^{1}$, Mario luiz Ribeiro Monteiro ${ }^{1}$, Celso Morita ${ }^{1}$, John Helal Junior ${ }^{1}$, Leandro Cabral Zacharias ${ }^{1}$, Daniel Araújo Ferraz ${ }^{1}$, David E. Pelayes ${ }^{2}$, Walter Yukihiko Takahashi ${ }^{1}$

\begin{abstract}
This case report describes peripheral idiopathic polypoidal choroidal vasculopathy (IPCV) with a collection of small aneurysmal dilations that masqueraded as choroidal tumors in an elderly patient. A 68-year-old African American woman was referred to us with a suspected diagnosis of asymptomatic vascular choroidal tumor and choroidal capillary hemangioma, affecting the temporal peripheral fundus. Upon examination, optical coherence tomography (OCT) revealed two large hemorrhagic pigment epithelium detachments (PED), and indocyanine green angiography (ICG) confirmed the diagnosis of IPCV. One year later, there was reduction in the hemorrhagic pigment epithelium detachments and the lesion took on a different appearance, resembling a choroidal osteoma. No treatment was necessary despite the presence of multiple polyps. IPCV is a rare condition that can resemble other choroidal diseases depending on the stage of presentation. OCT is the best tool to determine the characteristics of the lesions, and indocyanine green angiography should be used to confirm the diagnosis. Not all cases require treatment.
\end{abstract}

Keywords: Choroid hemorrhage/etiology; Choroid diseases/pathology; Fluorescein angiography; Indocyanine green/diagnostic use; Choroid/blood supply; Peripheral vascular diseases; Pigment epithelium of eye; Tomography, optical coherence; Case reports

\begin{abstract}
RESUMO
Relato de um caso de vasculopatia polipoidal idiopática da coroide (IPCV) com múltiplas dilatações aneurismáticas em região temporal periférica da retina, em uma paciente idosa que assemelhou-se com alguns tumores de coroide no seguimento de um ano. Paciente de 68 anos da raça negra, assintomática, foi encaminhada com a hipótese diagnóstica de um tumor vascular de coroide e hemangioma capilar da coroide, em região temporal inferior periférica da retina. Ao exame de tomografia de coerência óptica (OCT) era observado dois grande descolamentos de epitélio pigmentado (DEP), sendo confirmado o diagnóstico de vasculopatia polipoidal idiopática da coroide pela angiografia com indocianina verde (ICG). Após um ano, houve absorção do descolamento do epitélio pigmentado hemorrágico assemelhando-se assim ao osteoma de coroide. Nenhum tratamento foi necessário apesar da quantidade dos pólipos. A vasculopatia polipoidal idiopática da coroide é uma doença rara que, dependendo do estágio da apresentação, pode se assemelhar com algumas doenças da coroide. A tomografia de coerência óptica pode ilustrar melhor as características das lesões e a ICG confirma o diagnóstico. Nem todos os casos necessitam ser tratados.
\end{abstract}

Descritores: Hemorragia da coroide/etiologia; Doenças da coroide/patologia; Angiofluoresceinografia; Verde indocianina/uso diagnóstico; Coroide/irrigação sanguínea Doenças vasculares periféricas; Epitélio pigmentado ocular; Tomografia de coerência óptica; Relatos de casos

\section{INTRODUCTION}

Idiopathic polypoidal choroidal vasculopathy (IPCV) is a vascular malformation of the choroid, comprising a network of branching vessels of varying sizes that produce aneurysmal-like enlargements. This disease is generally observed in the peripapillary area, and less commonly as an isolated macular lesion (1).

Frequently, the IPCV vascular network is associated with multiple episodic serosanguineous detachments of the retinal pigment epithelium and neurosensory retina, which occasionally lead to sub-retinal $\left.\right|^{(1-3)}$ and on rare occasions vitreous ${ }^{(4)}$ hemorrhage. When the vascular network is beneath the atrophied pigment epithelium, a clinical diagnosis of IPCV is recommended if reddish orange, spheroidal, or polyp-like structures are observed. Nevertheless, in the majority of cases these lesions are not clearly visible, and indocyanine green angiography (ICG) is required for diagnosis ${ }^{(2,3)}$.

ICG images illustrate two components of vascular abnormalities in the choroidal circulation: 1) a branching vascular network and 2) aneurysmal dilations at the end of the vascular network branch. These dilations can also be divided into two patterns: 1) large solitary round aneurysmal dilations, which usually present a stable and favorable clinical course and 2) a collection of small aneurysmal dilations resembling a cluster of grapes, which tend to bleed or leak and cause severe visual los( ${ }^{(5)}$.

Optical coherence tomography (OCT) is another exam used to characterize the IPCV lesion ${ }^{(6)}$, and is used mainly when retinal pigment epithelium and serous retinal detachment are suspected ${ }^{(7)}$. However, this approach has not yet been described in peripheral IPCV.

A major problem with the diagnosis of peripheral IPCV is that it masquerades as several mass lesions or tumors, such as acquired vasoproliferative disease, metastatic lesions to the choroid, choroidal melanoma, or choroidal osteoma. The goal of this case report was to elucidate the diagnosis of a temporal lesion that mimicked a tumor mass, as well as describe the follow-up approach for assessing treatment need if the patient's vision becomes threatened or compromised.
Funding: No specific financial support was available for this study.

Disclosure of potential conflicts of interest: None of the authors have any potential conflict of interest to disclose.

Corresponding author: Rony Carlos Preti. Av. Ramalho Ortigão, 269/ 54 - São Paulo, SP - 04130-010 - Brazil - E-mail: preti@usp.br 


\section{CASE REPORT}

A 68-year-old asymptomatic African American woman was referred to us with a suspected diagnosis of vascular choroidal tumor and choroidal capillary hemangioma. The patient had lived with systemic arterial hypertension for 18 years, which was treated with enalapril maleate ${ }^{\circledR}$ at $25 \mathrm{mg}$ per day, and diabetes mellitus for 1 year, which was treated with metformin at $850 \mathrm{mg}$ twice per day.

Upon initial examination, the patient's visual acuity was 20/20 in both eyes, she had no afferent pupillary defects, and had normal intraocular pressure measurements. Slit-lamp examination revealed only pinguecula on the right eye (OD) and asteroid hyalosis in the left eye (OS). Upon fundus examination of OD, there was an elevated lesion in the middle periphery of the inferior temporal region adjacent to multiple areas of pigment epithelium detachment (PED). In addition, at 2 o'clock in relation to the lesion, a peculiar, smaller elevation resembling a vascular tumor (Figure 1A) was observed.

The OCT examination of the major lesion in OD revealed a large PED with adjacent smaller lesions resembling a vascular tumor, and these observations were correlated with retinal serous detachment (Figure 2). Fluorescein angiography of OD showed a patchy area of subretinal staining of undetermined origin, with minimal leakage
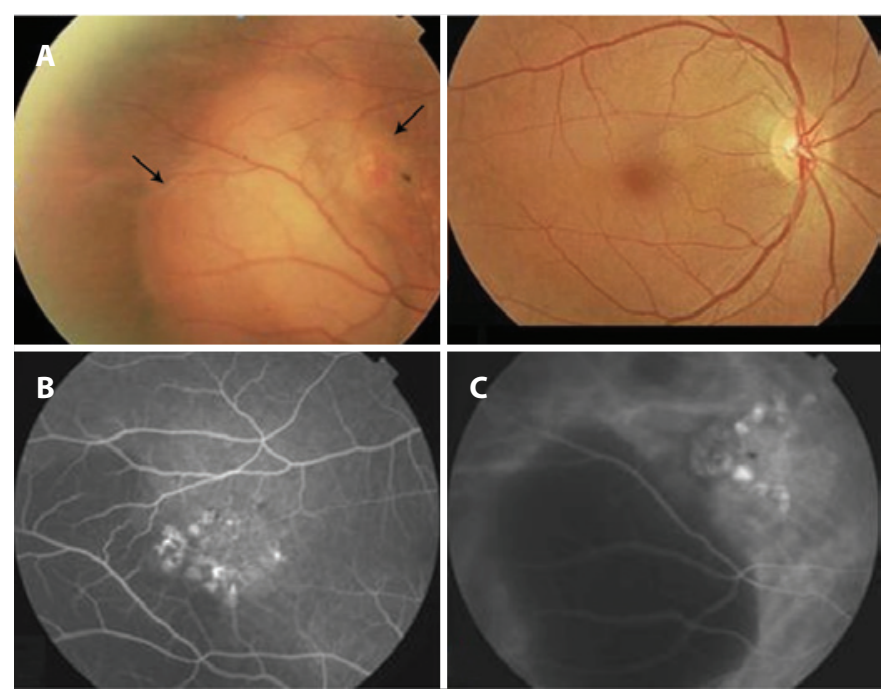

Figure 1.A) Fundus retinography demonstrating an elevated lesion in the mid-periphery of the inferior temporal vascular arcade, as shown by the long black arrow, and a lesion resembling the vascular tumor at the $20^{\prime}$ clock position, as shown by the short black arrow. B) Right fundus. A middle phase of the fluorescein angiography showing minimal leakage and pooling. C) Indocyanine green angiogram showing the tubular elements ending in aneurysmal or polypoidal dilatations with little leakage of the dye. In both exams, the lack of fluorescence (i.e., black appearance) was due to major hemorrhagic pigment epithelium detachment.

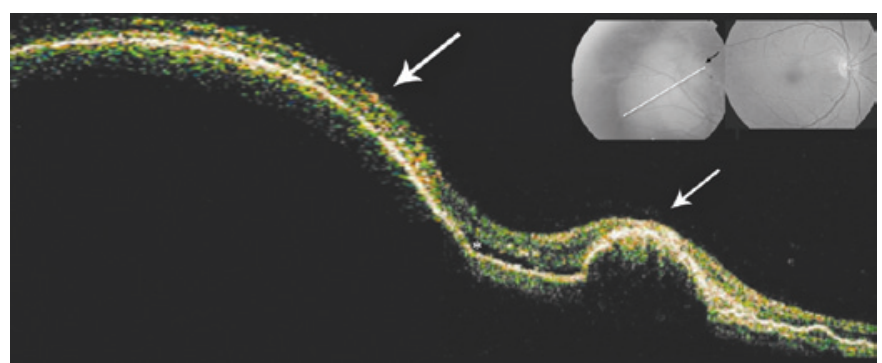

Figure 2. OCT showing the larger lesion, represented by the long white arrow, and the smaller lesion, represented by the short white arrow, corresponding to hemorrhagic pigment epithelium detachments (PED). Note the presence of serous retinal detachment, as shown by the asterisk, and multiples areas of PED on the right. and a blockage area corresponding to the elevated lesion (Figure 1B). ICG revealed the presence of an inner choroidal vascular abnormality that ended in multiple small, hyperfluorescent polyps with leakage characteristic of IPCV, as well as a permanent blockage area observed during all phases of the angiogram, which corresponded to the major PED (Figure 1C). No macular changes were observed. One year later, there was decreased dimension and discoloration of the lesions, which now resembled a choroidal osteoma (Figure 3). After the initial visit no treatment was administered, because the macula was not threatened.

\section{DISCUSSION}

Recent findings have expanded our knowledge surrounding the nature of the vascular lesions that occur during the course of $I P C V^{(4)}$. The most common region of occurrence is the peripapillary or macular area, and even in these cases the diagnosis is challenging due to variability in disease presentation, as well as the fact that this condition is uncommon and can only be confirmed using ICG ${ }^{(2)}$. Therefore, patients suffering from this disease are almost always initially diagnosed with malignant tumor lesions.

In the first case of peripheral IPCV ${ }^{(9)}$, the patient demonstrated characteristic peripheral subretinal hemorrhage associated with hard exudates, and was free of systemic disorders. Our patient presented a similar lesion location (temporal inferior), but did not show hemorrhage or hard exudates, possibly due to its benign course.

In the case described here, the use of OCT was important, because it permitted the observation of multiple serosanguineous detachments of the retinal pigment epithelium, and neurosensory retina isolated between the two PED that was not threatened. Moreover, the approach enabled the detection of a major lesion that resembled a tumor, but was instead correctly identified as a major PED.

A major strength of this case, which we followed for one year, was that the differential diagnosis performed early after disease onset included vasoproliferative acquired disease, capillary hemangioma, focal posterior scleritis, and primary tumor. However, in the late phase (Figure 3), due to the appearance of discolored lesions likely associated with the absorption of blood, potential diagnoses suggested were metastatic tumors and choroidal osteoma.

Consistent with a previous report ${ }^{(2)}$, ICG was essential in establishing a diagnosis of IPCV in this patient, because it uncovered polypoidal and aneurysmal dilations at the terminals of the branching vascular network ${ }^{(10)}$. The patient presented with a peripheral collection of small aneurysmal dilations, which is a risk factor for bleeding that can lead to vision loss and has a poor prognosis. However, the disease course in this patient has been benign and was appropriately identified within a year.

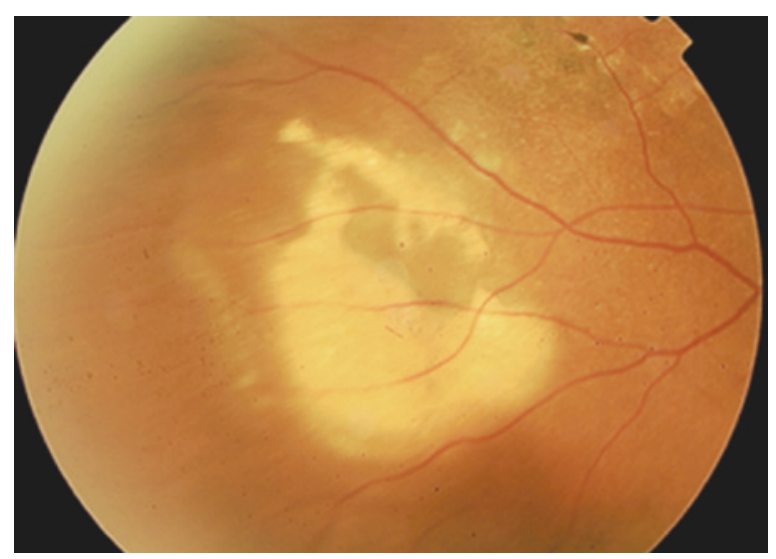

Figure 3. Peripheral retinography of $O D$ ayear after diagnosis of thelesion. Note that the lesions changed, showing discoloration and a decrease in dimension. 
No treatment was administered to this patient, because there was no subretinal fluid accumulation, hard exudates, or hemorrhage threatening the fovea. This patient is currently under continued observation.

\section{REFERENCES}

1. Yannuzzi LA, Ciardella A, Spaide RF, Rabb M, Freund KB, Orlock DA. The expanding clinical spectrum of idiopathic polypoidal choroidal vasculopathy. Arch Ophthalmol. 1997:115(4):478-85

2. Spaide RF, Yannuzzi LA, Slakter JS, Sorenson J, Orlach DA. Indocyanine green videoangiography of idiopathic polypoidal choroidal vasculopathy. Retina. 1995;15(2):100-10.

3. Yannuzzi LA, Sorenson J, Spaide RF, Lipson B. Idiopathic polypoidal choroidal vasculopathy (IPCV). Retina. 1990;10(1):1-8.

4. Barreira IM, Aragão RE, Vale AB, Holanda Filha JG. [Idiopathic polypoidal choroidal vasculo- pathy: its icpvextreme aspects in one patient--case report]. ArqBras Oftalmol. 2005; 68(2):253-6. Portuguese.

5. Uyama M, Wada M, Nagai Y, Matsubara T, Matsunaga H, Fukushima I, et al. Polypoidal choroidal vasculopathy: natural history. Am J Ophthalmol. 2002;133(5):639-48.

6. Andrade RE. Vasculopatiapolipoidalidiopatica da coroide. Arq Bras Oftalmol. 2002; 65(3):363-6.

7. lijima H, lida T, Imai M, Gohdo T, Tsukahara S. Optical coherence tomography of orange-red subretinal lesions in eyes with idiopathic polypoidal choroidal vasculopathy. Am J Ophthalmol. 2000;129(1):21-6.

8. Lafaut BA, Leys AM, Snyers B, Rasquin F, De Laey JJ. Polypoidal choroidal vasculopathy in Caucasians, Graefes Arch Clin Exp Ophthalmol. 2000:238(9):752-9.

9. Yannuzzi LA, Nogueira FB, Spaide RF, Guyer DR, Orlock DA, Colombero D, et al. Idiopathic polypoidal choroidal vasculopathy: a peripheral lesion. Arch Ophthalmol. 1998; 116(3):382-3.

10. Uyama M, Matsubara T, Fukushima I, Matsunaga H, Iwashita K, Nagai Y, et al. Idiopathic polypoidal choroidal vasculopathy in Japanese patients. Arch Ophthalmol. 1999;117(8): 1035-42.

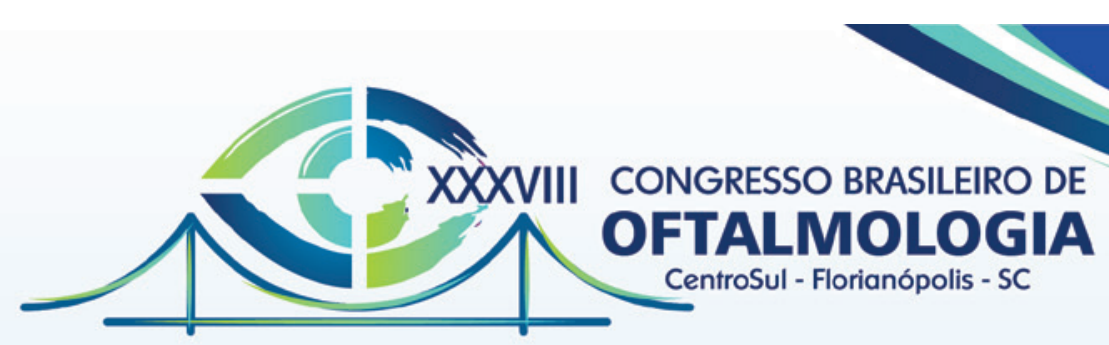

2 a 5 de setembro de 2015

\section{Floripa te espera em 2015 para o maior evento da oftalmologia do Brasil.}

A bela capital catarinense será mais uma vez palco deste que é considerado o maior e mais importante evento da oftalmologia no Brasil. Os maiores nomes nacionais e internacionais estarão presentes.

Palestras, Stands, Exposição de Trabalhos Científicos e muito mais.

Esperamos por você!

\section{Floripa2015} cbo2015.com.br

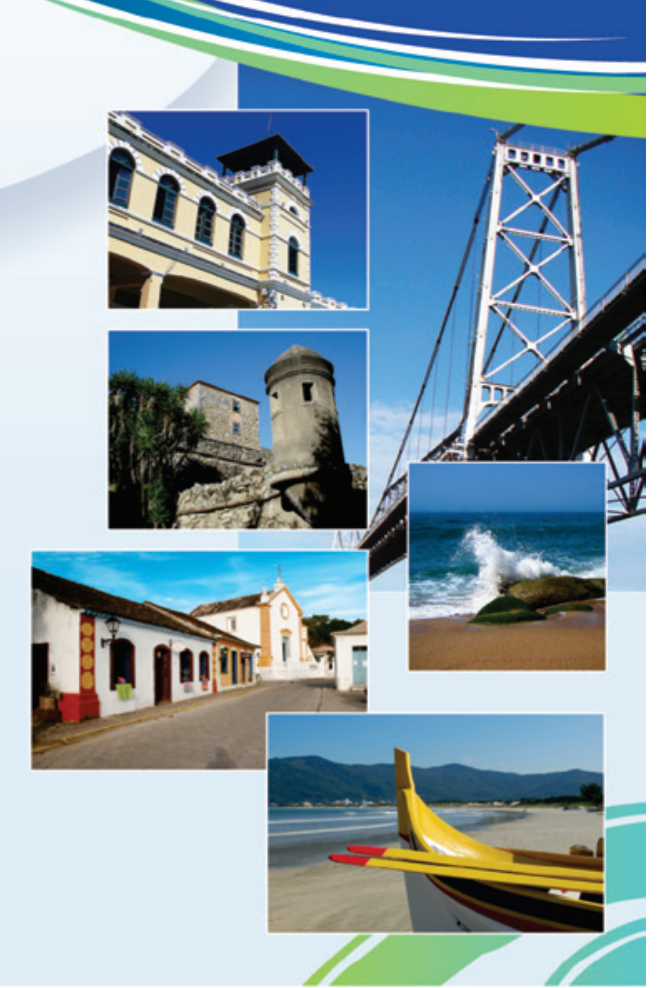

APOIO

ORGANIZAÇAOO

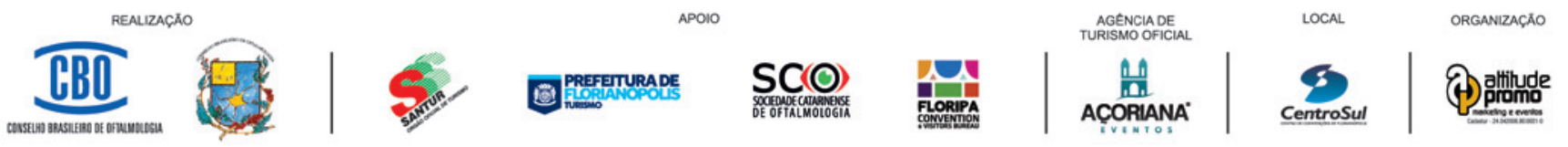

